\title{
Słyszące rodzeństwo osób z wadą słuchu (SODA) - studium indywidualnych przypadków
}

\begin{abstract}
Aleksandra Rożek, Styszące rodzeństwo osób z wada stuchu (SODA) studium indywidualnych przypadków [Hearing siblings of persons with hearing loss]. Interdyscyplinarne Konteksty Pedagogiki Specjalnej, nr 18, Poznań 2017. Pp. 131-143. Adam Mickiewicz University Press. ISSN 2300-391X

The article describes the functioning hearing siblings of persons with hearing loss in the different developmental stages: childhood, adolescence and adulthood. Indicated determinants of building positive relationships between deaf and hearing siblings. They may implicite the psychosocial functioning of hearing people in adulthood.
\end{abstract}

KEY WORDS: siblings, deafness, reationships

Macierzyństwo, jak również ojcostwo dzieci chorych i niepełnosprawnych stało się przedmiotem wielu badań. Trzeba jednak pamiętać, że problemy w rozwoju dziecka wpływają na dobrostan i jakość życia wszystkich członków rodziny. Niedocenianie trudności, jakich doświadcza rodzeństwo dziecka z niepełnosprawnością, należy uznać za istotne przeoczenieํ. Jak zauważa Iwona Przybył,

${ }^{1}$ E. Pisula, Rodzice $i$ rodzeństwo dzieci z zaburzeniami rozwoju, Wydawnictwo Uniwersytetu Warszawskiego, Warszawa 2007, s. 122. 
relacja, która zachodzi między rodzeństwem jest szczególna, ponieważ wyróżnia ją m.in. czas trwania - ma ona zdecydowanie dłuższy przebieg niż jakikolwiek inny związek społeczny. Poza tym „jest relacją przypisaną, a jednocześnie egalitarną, przesyconą długą historią swoistych intymnych doświadczeń, nie do odtworzenia w innych zbiorowościach"2 ${ }^{2}$. Warto jeszcze nadmienić, iż zdaniem Victora Cicirelliego rodzeństwo można rozpatrywać z dwóch perspektyw: formalno-biologicznej oraz psychologicznej. Pierwsza zwraca uwagę na fakt, że rodzeństwo łączy pokrewieństwo biologiczne, z kolei druga, że rodzeństwo stanowi sumę interakcji jednostek posiadających tych samych rodziców biologicznych, a ponadto wspólną wiedzę, opinie, pewien stosunek do postrzegania siebie nawzajem ${ }^{3}$.

Co istotne, z dostępnych źródeł teoretycznych wynika, iż wśród badaczy zwiększa się zainteresowanie kwestią funkcjonowania rodzeństwa dzieci (dorosłych) niepełnosprawnych. Kierowana chęcią zgłębienia powyższej problematyki uczyniłam rodzeństwo osób niesłyszących głównym podmiotem swoich badań do pracy dyplomowej. Dążenie do autentycznego zrozumienia ludzkich doświadczeń zostało zrealizowane dzięki bezpośrednim i pośrednim rozmowom (wywiady) z dorosłymi osobami słyszącymi posiadającymi niesłyszące rodzeństwo.

\section{Rodzeństwo osób z wadą słuchu}

Biorąc pod uwagę oczekiwania i postawy rodziców wobec słyszącego dziecka, istotnymi kwestiami są: wiek niesłyszącego rodzeństwa względem słyszącego, jego płeć oraz kolejność narodzin. Dotychczasowe badania pokazują, że inne doświadczenia mają sły-

2 I. Przybył, Siostry i bracia dzisiaj. Gwarancja i niepewność w relacji - nowe hipotezy na podstawie badań ankietowych, [w:] Role rodzinne między przystosowaniem a kreacja, red. I. Przybył, A. Żurek, Wydawnictwo Naukowe Wydziału Nauk Społecznych Uniwersytetu im. Adama Mickiewicza, Poznań 2016, s. 165.

3 Ibidem, s. 166. 
szące starsze siostry dzieci z wadą słuchu niż starci bracia, co stanowi rezultat oczekiwań społecznych wobec dziewczynek dotyczący sprawowania opieki i zajmowania się rodzeństwem. W sytuacji, „gdy słyszące rodzeństwo jest dzieckiem młodszym niż głuche dziecko, wówczas przychodzi ono na świat w «dobrym momencie», gdyż świat jest już zorganizowany i rodzina, choć w różnym stopniu, ułożyła sobie życie, w którym istnieje i współtworzy je starsze niesłyszące dziecko" 4 . Natomiast gdy to dziecko niesłyszące pojawia się na świecie jako kolejne w słyszącej rodzinie, mamy do czynienia z sytuacją odwrotną - dla dzieci słyszących pojawienie się rodzeństwa z wadą słuchu oznacza zmianę na „niekorzyść”, przeorganizowanie życia, pojawienie się negatywnych emocji i napięć, zmianę oczekiwań względem nich, brak zrozumienia dlaczego niesłyszące rodzeństwo zachowuje się w sposób odmienny niż inne dzieci ${ }^{5}$. Wyniki badań wskazują, iż niepełnosprawność rodzeństwa (niezależnie od rodzaju i stopnia niepełnosprawności) w największym stopniu niekorzystnie wpływa na najstarsze siostry, które w porównaniu z rówieśniczkami posiadającymi zdrowe rodzeństwo aż czterokrotnie częściej występują w roli opiekunek i nauczycielek. Słyszące siostry m.in. dbają o utrzymanie porządku, zajmują się przygotowaniem posiłku, kąpią i karmią rodzeństwo z niepełnosprawnością, odprowadzają i przyprowadzają je ze szkoły lub przedszkola i wychodzą z nim na spacery. Nałożone obowiązki w znacznym stopniu ograniczają możliwość zaspokajania własnych potrzeb, rozwijania zainteresowań, czy utrzymywania relacji z rówieśnikami6. Starsi bracia posiadający rodzeństwo z niepełnosprawnością również znacznie częściej niż rówieśnicy z grupy kontrolnej zajmują się bratem lub siostrą i tak często jak starsze siostry mające rodzeństwo rozwijające się prawidłowo. Zarówno starsi bracia

${ }^{4}$ J. Kobosko, J. Kosmalowa, Styszące rodzeństwo dzieci głuchych i stabostyszącychspojrzenie z różnych stron, „Słyszę. Dwumiesięcznik dla osób z problemami słuchu i mowy" wrzesień-październik 2010, s. 29.

${ }^{5}$ Ibidem.

${ }^{6}$ A. Twardowski, Sytuacja psychologiczna rodzeństwa dzieci z niepetnosprawnościami (część 1), „Szkoła Specjalna” 2011, 2, s. 96. 
dzieci niepełnosprawnych, jak i bracia dzieci nieposiadających problemów zdrowotnych częściej niż starsze siostry podejmują prace w przydomowym ogródku, sprzątają obejście domu czy pracują w garażu. Nie zajmują się natomiast karmieniem i kąpaniem rodzeństwa. Ponadto starsi bracia rodzeństwa z niepełnosprawnością utrzymują kontakty z gronem koleżeńskim i przyjaciółmi częściej niż starsze siostry, co ma miejsce w domu, jak i poza nim7.

Zdarza się, że oczekiwania [rodziców] są nieadekwatne do indywidualnych potrzeb rozwojowych i emocjonalnych, i przerastają realne możliwości rodzeństwa. Sytuacja staje się szczególnie trudna wówczas, gdy jest duża różnica wieku między słyszącym rodzeństwem a jego niepełnosprawnym bratem czy siostrą. Przypisana rola opiekuna może utrudniać proces separacji od rodziny młodemu człowiekowi wkraczającemu w okres adolescencji. $\mathrm{Z}$ drugiej strony czasem paradoksalnie proces ten może być ułatwiony dla młodego człowieka, który do tej pory był włączony $\mathrm{w}$ diadę małżeńską ${ }^{8}$.

Z całą pewnością rodzice posiadający słyszące i niesłyszące potomstwo doświadczają licznych trudności w sferze wychowania. Duże wyzwanie stanowi zapobieganie wzajemnej szkodzie rodzeństwa, nauka wzajemnego zrozumienia, akceptacji i miłości. Obawa rodziców o spowolnienie rozwoju „zdrowego" dziecka lub przejęcie zachowań niepożądanych niesłyszącego rodzeństwa zmaga się z potrzebą wzmacniania więzi między dziećmi ${ }^{9}$. Niełatwo jest rodzicom wyznaczać rozsądne granice między obowiązkami a niebezpieczeństwem przeciążenia słyszących dzieci sprawowaniem opieki nad rodzeństwem z wadą słuchu. Rodzice (a przede wszystkim matki) całkowicie oddani wychowaniu słuchowemu na ogół nieświadomie i wbrew najlepszym intencjom, by pomóc przede

7 Ibidem, s. 96-97.

8 A. Wzorek, Rodzina z dzieckiem z zaburzeniem stuchu- spojrzenie systemowe, „Psychoterapia" 2009, 4(151), s. 57.

${ }^{9}$ A. Kucharczyk, Kiedy w rodzinie nie wszystkie dzieci styszą..., [w:] Młodzież głucha $i$ stabo styszaca w rodzinie $i$ otaczajacym świecie dla terapeutów, nauczycieli, wychowawców i rodziców, red. J. Kobosko, Stowarzyszenie Rodziców i Przyjaciół Dzieci i Młodzieży z Wadą Słuchu „Usłyszeć Świat”, Warszawa 2009, s. 137-138. 
wszystkim „bardziej potrzebującemu”, koncentrują się na osobie dziecka niesłyszącego, marginalizując tym samym potrzeby pozostałych dzieci i osłabiając ich potencjał ${ }^{10}$. W niektórych rodzinach słyszące rodzeństwo odgrywa rolę pośrednika między niesłyszącym bratem lub siostrą a rodzicami, kiedy to w przeciwieństwie do opiekunów, spontanicznie nauczy się języka migowego od niesłyszącego rodzeństwa. Zdarza się także, że rodzice stosują odmienny system kar i nagród, faworyzując w ten sposób dziecko z wadą słuchu lub jego rodzeństwo. Porównywanie dzieci np. na zasadzie „niesłyszące dziecko jest poszkodowane przez los” czy „chore dziecko kocha się inaczej", jak również jaskrawe odróżnianie destruktywnie wpływa na relacje między rodzeństwem i świadczy o nieprawidłowych relacjach w danej rodzinie ${ }^{11}$.

Badania poświęcone sytuacji rodzeństwa dzieci niesłyszących dostarczają sprzecznych informacji: niektóre sugerują, że słyszące rodzeństwo jest narażone na stres i może doświadczać trudności $\mathrm{z}$ dostosowaniem społecznym ${ }^{12}$. Jak podają Joanna Kobosko i Joanna Kosmalowa,

zdarza się, że słyszące rodzeństwo staje się niegrzeczne, przeszkadza, buntuje się, a nawet zaczyna stwarzać problemy: ma trudności w szkole czy jest agresywne wobec kolegów, przejawia w sposób jawny lub ukryty zachowania rywalizacyjne wobec głuchego brata lub siostry, a wszystko po to, by przywrócić zachwianą równowagę, swoje miejsce $\mathrm{w}$ rodzinie ${ }^{13}$.

Inni autorzy podkreślają, że u rodzeństwa nie muszą zachodzić problemy przystosowawcze i emocjonalne. Fakt posiadania brata lub siostry z niepełnosprawnością może przyczynić się do gromadzenia pozytywnych doświadczeń przez rodzeństwo - m.in. stwa-

${ }^{10}$ J. Kobosko, J. Kosmalowa, Nasze styszące dzieci, „Słyszę. Dwumiesięcznik dla osób z problemami słuchu i mowy" październik 2002, s. 22.

11 J. Kobosko, J. Kosmalowa, Styszące rodzeństwo dzieci głuchych..., s. 30.

12 U. Bartnikowska, Sytuacja społeczna i rodzinna styszacych dzieci niestyszacych rodziców, Wydawnictwo Edukacyjne Akapit, Torun 2010, s. 53.

${ }^{13}$ J. Kobosko, J. Kosmalowa, Styszące rodzeństwo dzieci głuchych..., s. 29. 
rzać sposobność do rozwoju postaw prospołecznych i tolerancji dla szeroko rozumianej inności14. Wśród "zysków”, jakie odnosi rodzeństwo dzieci niesłyszących, wyróżnić można: większą niezależność, lepiej rozwiniętą empatię i umiejętność współpracy. Te rozbieżne wyniki badań wskazują na wieloczynnikowe uwarunkowanie sytuacji dzieci w rodzinie ${ }^{15}$.

Kondycja rodziny w jakiej niesłyszące dziecko przyszło na świat ma kluczowe znaczenie dla kształtowania się relacji między dzieckiem (a później dorosłym) a jego niesłyszącym rodzeństwem. Jak ta rodzina radziła sobie $\mathrm{w}$ momencie wystąpienia trudnych sytuacji do momentu narodzin dziecka z wadą słuchu, jaka atmosfera panuje w rodzinie, jak rodzina obecnie radzi sobie w procesie adaptacji do głuchoty dziecka. Ponadto: jaki styl wychowawczy stosują rodzice, w jaki sposób rozwiązują pojawiające się konflikty, czy potrafią okazywać wspólnie przeżycia związane z głuchotą, czy potrafią korzystać z pomocy i wsparcia najbliższych i dalszego otoczenia16. Duże znaczenie dla przystosowania się rodzeństwa mającego niepełnosprawnego brata lub siostrę odgrywa zasób informacji na temat zaburzenia - im większy stan wiedzy, tym pozytywniejszą postawę prezentuje dziecko wobec chorego rodzeństwa, a ponadto mniej negatywnie ocenia wpływ zaburzenia/choroby na funkcjonowanie rodziny i częściej doświadcza pozytywnego nastroju ${ }^{17}$. Na jakość relacji między rodzeństwem znacząco wpływa także możliwość komunikowania się. Doświadczane trudności w porozumiewaniu się utrudniają budowanie i pielęgnowanie więzi psychicznych między rodzeństwem, a także akceptację niesłyszącego brata czy siostry przez dziecko słyszące ${ }^{18}$.

14 Ż. Stelter, Realizacja ról rodzinnych $w$ rodzinie z dzieckiem niepetnosprawnym, [w:] Rodzina z dzieckiem niepetnosprawnym- możliwości i ograniczenia rozwoju, red. H. Liberska, Difin, Warszawa 2011, s. 83.

15 U. Bartnikowska, op. cit.

16 J. Kobosko, J. Kosmalowa, Styszące rodzeństwo dzieci głuchych..., s. 29.

${ }^{17}$ E. Pisula, Rodzice i rodzeństwo dzieci z zaburzeniami rozwoju, Wydawnictwo Uniwersytetu Warszawskiego, Warszawa 2007, s. 126.

18 A. Kucharczyk, op. cit., s. 140. 
Rewalidacja niesłyszącego dziecka w dużej mierze polega na kształtowaniu mowy i języka. Słyszące rodzeństwo tworzy specyficzną grupę rówieśniczą skupioną wokół brata lub siostry z wadą słuchu i odgrywa w niej rolę partnera, towarzysza zabawy. Dziecko $\mathrm{z}$ niepełnosprawnością $\mathrm{w}$ kontakcie $\mathrm{z}$ rodzeństwem zaspokaja swoje potrzeby, takie jak: potrzeba kontaktu emocjonalnego, bezpieczeństwa, szacunku czy ruchu19. Mając na uwadze dobro wszystkich dzieci w rodzinie, rodzice powinni pamiętać o tym, że słyszące dzieci mają pełne prawo do własnego dzieciństwa i nie można przeciążać ich obowiązkami względem niesłyszącego rodzeństwa ${ }^{20}$.

Trudno dać jednoznaczną odpowiedź na pytanie: jak to jest być bratem lub siostrą osoby niesłyszącej? U części dorosłego słyszącego rodzeństwa rodzi się potrzeba poszukiwania wsparcia i zrozumienia dla swojego niesłyszącego brata lub siostry. Jednym ze źródeł informacji i pomocy skierowanym do słyszącego rodzeństwa są portale i strony internetowe SODA (Siblings od Deaf Adults). SODA to Rodzeństwo Głuchych Dorosłych. Słyszące dzieci wzrastające u boku niesłyszącego rodzeństwa mają wyjątkowe doświadczenia. Niektóre z tych osób chciałyby dotrzeć do innych słyszących mających niesłyszące rodzeństwo, aby dzielić się swoimi doświadczeniami ${ }^{21}$. Słyszące rodzeństwo często wypowiada się na forach internetowych dla osób niesłyszących i angażuje w sprawy społeczności osób z uszkodzonym słuchem. W niektórych przypadkach radzenie sobie z trudnościami odbywa się poprzez wybór studiów surdopedagogicznych czy też pisanie pracy dyplomowej w obrębie pedagogiki specjalnej. Niekiedy słyszący brat lub siostra zostaje tłumaczem języka migowego albo nauczycielem dzieci z wadą słuchu²2.

${ }^{19}$ A. Twardowski, Sytuacja psychologiczna rodzeństwa dzieci z niepetnosprawnościami (część 2), „Szkoła Specjalna” 2011, 3, s. 191.

${ }^{20} \mathrm{~K}$. Bieńkowska-Robak, Udział rodziny w terapii dziecka $z$ wada stuchu prowadzonej metoda audytywnowerbalna, [w:] Dziecko niepetnosprawne, jego rodzina i edukacja, red. K. J. Zabłocki, Wydawnictwo Akademickie „Żak”, Warszawa 1999, s. 183.

${ }^{21} \mathrm{~J}$. Berke, Sibling of Deaf Adult, http://deafness.about.com/od/hearingba sic1/g/sodadef.htm [dostęp: 17.01.2014].

22 J. Kobosko, J. Kosmalowa, Styszące rodzeństwo dzieci głuchych..., s. 30-31. 


\section{Metodologia badań}

Główny problem podjętych badań dotyczył tego, czy i w jaki sposób fakt posiadania rodzeństwa z wadą słuchu wpływa (wpłynął) na sytuację życiową słyszącego rodzeństwa. W celu udzielenia odpowiedzi na postawione pytanie zastosowano metodę indywidualnych przypadków. Badana populacja została wyodrębniona poprzez zastosowanie metody kuli śnieżnej ${ }^{23}$. Uczestniczyło $w$ nich sześcioro respondentów - cztery kobiety oraz dwóch mężczyzn (w przedziale wiekowym 20-50 lat). Osoby te mieszkają w różnych rejonach Polski, różnią się poziomem i kierunkiem wykształcenia, stanem cywilnym oraz wielkością miejsca zamieszkania. Rozmowę przeprowadzono w oparciu o kwestionariusz wywiadu - częściowo skategoryzowany - pozwalający na dostosowanie treści i kolejności pytań, a także wprowadzanie pytań dodatkowych. Wybór ten uwarunkowany był zróżnicowanym charakterem funkcjonowania osób $\mathrm{z}$ wadą słuchu. M.in. wiedza na temat sposobu porozumiewania się tych osób czy też specyfika szkoły, do której uczęszczały, determinowały sposób, treść i kolejność zadawania pytań w rozmowie ze słyszącym rodzeństwem. W celu wiernego utrwalenia wypowiedzi badanych podczas przeprowadzanego z nimi wywiadu wykorzystano nagranie dyktafonowe za zgodą respondentów.

\section{Wyniki badań własnych}

Podejmując się przeprowadzenia badań jakościowych, musiałam przyjąć założenie, iż "ograniczenie się do jednego lub kilku przypadków może dawać jedynie podstawę do formułowania hipotez roboczych, a nie do wyciągania wniosków o charakterze ogólnym" 24 .

${ }^{23}$ E. Babbie, Badania społeczne w praktyce, Wydawnictwo Naukowe PWN, Warszawa 2003, s. 205-206.

${ }^{24}$ U. Bartnikowska, op. cit., s. 167. 
Retrospektywne spojrzenie dorosłego rodzeństwa na kwestię osobistych doświadczeń z okresu dzieciństwa u boku niesłyszącego brata lub siostry bywa różnorodne ${ }^{25}$. Ze względu na ograniczoną objętość niniejszego opracowania prezentuję fragmentaryczne wypowiedzi respondentów. Jedna z moich rozmówczyń - dwudziestoczteroletnia pani Agnieszka, studentka pedagogiki - spontanicznie nauczyła się (i nadal uczy) języka migowego od siostry, czego nie uczynili w takim zakresie jej rodzice. Tym samym w wielu sytuacjach stała się pośrednikiem w ich wzajemnym komunikowaniu się. Literatura przedmiotu opisuje tego rodzaju przypadki, o czym wspomniałam w początkowej części niniejszego artykułu:

Chyba to przyszło tak samo z siebie. Ja wiedziałam, że ona nie styszy, że nie dogadam się werbalnie, tylko trzeba coś zrobić innego, no to gesty, no to wskazywanie, no to coś. Myśle, że to na tej zasadzie gdzieś to przychodziło. No i ja automatycznie, i ona też mi pokazywała, jak ona sie uczyła tego języka migowego, to przynosiła to do domu, no i ja się przy okazji też tego gdzieś tam uczyłam. Nie pamiętam takiego punktu "no naucz się języka migowego. Ucz się musisz umieć, bo musisz się ze mna dogadać". To przychodziło ptynnie i my tak między soba, same ze soba.

Zdaniem dwudziestoczteroletniej pani Marty, studentki pedagogiki, posiadanie niepełnosprawnego rodzeństwa $\mathrm{w}$ pewien sposób kształtuje cechy osobowościowe, i w związku z tym postrzega ona siebie jako osobę tolerancyjną dla inności. Podczas wypowiedzi stwierdziła, że

Coś w tym jest, inaczej patrzymy [...]. I też na pewno wyglada to też tak, że jeżeli ktoś inny przychodzi np. z inna wada, z jakąś tam niepetnosprawnościa w jakimś stopniu, to podchodze do niego bardziej normalnie, bo ja mam to na co dzień... i to jest da mnie takie normalne [...], człowiek jak każdy inny.

25 Cyran A., Styszace rodzeństwo osób z zaburzeniem stuchu, praca magisterska napisana pod kierunkiem prof. UAM dr hab. H. Krauze-Sikorskiej, Uniwersytet im. Adama Mickiewicza w Poznaniu, Poznań 2014. 
Pan Tomasz, dwudziestoczteroletni uczeń szkoły policealnej o kierunku informatycznym, dostrzegł korzyść wynikającą z faktu posiadania niesłyszącego rodzeństwa $\mathrm{w}$ postaci rozwoju własnej samodzielności:

Mi nawet to odpowiadało, że mogłem sam o sobie.., to znaczy może nie do końca sam o sobie decydować [...]. Ja po prostu nauczytem się samodzielności przez to [...]. Rodzice mi ufali, a ja ufatem im. [...]. I tego zaufania nigdy nie nadwyrężyłem.

W trakcie swojej wypowiedzi pan Mirosław, czterdziestosześcioletni kierownik sprzedaży, ojciec pięciorga słyszących dzieci, zasygnalizował znaczenie różnicy wieku między rodzeństwem dla kształtowania się wzajemnej relacji oraz podejmowania funkcji opiekuńczych:

Ja pamiętam bardzo dobrze, jak mój młodszy brat nie chciał zasnać, a koledzy szli grać w pitkę i mnie wołali, a ja nie mogłem wyjść i byłem bardzo wkurzony [śmiech], ale to jedyna taka sytuacja. Tu jednak duża różnica wieku była [...], raczej ten starszy się mna opiekowat, niż ja mu tak w jakiś sposób pomagatem. Natomiast młodszego brata, jak wspominatem, no wiadomo bytem troche starszy, czasami trzeba byto się nim zając [śmiech] czy tam "poziuziać" czy nie „poziuziać” [...], ale generalnie wszystko było ok.

Dwudziestotrzyletnia pani Anna, studentka bezpieczeństwa narodowego, w swojej wypowiedzi zwróciła uwagę na towarzyszące jej poczucie odpowiedzialności za niesłyszące rodzeństwo:

Bardzo dużo w ostatnim czasie o tym myślatam, bo jestem najstarsza $i$ czuje sie bardzo odpowiedzialna za to rodzeństwo moje i jestem tego pewna, jestem przygotowana, myślę, na to, że w przyszłości będe im tė̇ pomagać. Tak myślatam, że chciałabym mieć na tyle dobra pracę, $\dot{z}$ eby w razie czego im we wszystkim pomagać. Nigdy nie wiadomo, jak się życie potoczy. To znaczy konkretnych wyborów edukacyjnych i zawodowych pod ich katem nie podjętam, ale wiem że w przysztości będe na pewno za nich odpowiedzialna też w jakiś sposób. 
W przypadku pani Marzeny, czterdziestoośmioletniej matki trójki dzieci, fakt posiadania braci z wadą słuchu wpłynął na dokonywane przez nią wybory edukacyjne, a następnie zawodowe. Obecnie respondentka może wykazać się wieloletnią pracą w Ośrodku Szkolno-Wychowawczym dla Dzieci Niesłyszących. Jak sama mówi: to rzeczywiście miało wptyw na to, jak się potoczyło moje życie. Zdaniem rozmówczyni posiadanie niesłyszącego rodzeństwa

ma wptyw na postrzeganie osób, które moga się zachowywać inaczej czy bardziej rozumiem pewne sytuacje i mam większy dystans do tych sytuacji. Pewnie to miało jakiś wptyw, że inaczej patrze, inaczej czuję. Bo wydaje mi się, że jeśli pewnych rzeczy sami nie doświadczymy, to trudno tak wszystko właściwie przyjąć, czytając tylko artykuły czy ksiażki, nie mając takiego do świadczenia, nie obcując z osobami w ogóle niepetnosprawnymi. Pewnie, że jakaśs tam akceptacje czy tolerancje różni ludzie różna maja i można w przypadku doświadczeń jeszcze dodatkowych mieć większa ni $\dot{z}$ inni, ale ja myślę, że też to jest kwestia osoby.

Ponadto w wywiadzie zwróciła uwagę na postawę społeczną wobec niesłyszących oraz wynikającą z niej potrzebę udzielania wsparcia osobom z wadą słuchu:

generalnie problem jest jak zwykle w ludziach. Problem jest $w$ tym, że jedni sa otwarci i chca coś zrobić, a inni sq zamknięci i uważaja, że "ja $i$ tak wiem najlepiej $i$ co ty mi tu będziesz mówit". Wurzędach też wszystko zależy od ludzi.

\section{Refleksje końcowe}

Podjęte badania miały charakter jakościowy - losy i refleksje rozmówców można traktować wyłącznie jako przykład stanowiący punkt odniesienia. Zauważyć jednak należy pojawiające się w wypowiedziach badanych motywy determinujące kształtowanie pozytywnych relacji z niesłyszącym rodzeństwem. Należą do nich: 
zgodne postawy rodzicielskie względem słyszących i niesłyszących dzieci, znajomość metod porozumiewania się dostępnych rodzeństwu z wadą słuchu, a także zgodna, pełna miłości i zrozumienia atmosfera rodzinna. Duże znaczenie w tym aspekcie odgrywa już wspominana kolejność narodzin dziecka niesłyszącego oraz wielkość rodziny. Odnosząc się do głównego problemu prezentowanych badań, można stwierdzić, iż w przypadku opisanych indywidualnych przypadków fakt posiadania rodzeństwa z wadą słuchu wpłynął na sytuację życiową tych osób. Odnosi się on do przejawianych cech osobowościowych oraz wyborów w sferze edukacyjnej i zawodowej.

Aktualne wyzwanie stanowi poszukiwanie odpowiedzi na pytania: co zrobić, żeby słyszące rodzeństwo odnosiło jak najwięcej korzyści z sytuacji rodzinnej i społecznej, w której się znalazło?, jak również co zrobić, aby minimalizować ewentualne straty wynikające $\mathrm{z}$ faktu posiadania rodzeństwa $\mathrm{z}$ zaburzeniem słuchu? Bez wątpienia kluczową rolę w tym obszarze odgrywa udzielane słyszącemu dziecku (osobie) wsparcia emocjonalnego, umożliwiającego redukcję napięć i negatywnych uczuć26 oraz szeroko rozumianego wsparcia społecznego ${ }^{27}$.

\section{Bibliografia}

Babbie E., Badania społeczne w praktyce, Wydawnictwo Naukowe PWN, Warszawa 2003.

Bartnikowska U., Sytuacja społeczna i rodzinna styszacych dzieci niestyszacych rodziców, Wydawnictwo Edukacyjne Akapit, Torun 2010.

Berke J., Sibling of Deaf Adult, http://deafness.about.com/od/hearingbasic1/g/ sodadef.htm [dostęp: 17.01.2014].

${ }^{26}$ H. Sęk, R. Cieślak, Wsparcie społeczne- sposoby definiowania, rodzaje $i$ źródła wsparcia, wybrane koncepcje teoretyczne, [w:] Wsparcie społeczne, stres $i$ zdrowie, red. H. Sęk, R. Cieślak, Wydawnictwo Naukowe PWN, Warszawa 2004, s. 19.

${ }_{27}$ M. Winiarski, Pedagogika społeczna humanistycznie zorientowana, [w:] Pedagogika społeczna: dokonania-aktualności-perspektywy. Podręcznik akademicki dla pedagogów, red. S. Kawula, Wydawnictwo Adam Marszałek, Torun 2001, s. 72-73. 
Bieńkowska-Robak K., Udziat rodziny w terapii dziecka z wada stuchu prowadzonej metoda audytywnowerbalna, [w:] Dziecko niepetnosprawne, jego rodzina i edukacja, red. K.J. Zabłocki, Wydawnictwo Akademickie „Żak”, Warszawa 1999.

Cyran A., Styszące rodzeństwo osób z zaburzeniem stuchu, praca magisterska napisana pod kierunkiem prof. UAM dr hab. H. Krauze-Sikorskiej, Uniwersytet im. Adama Mickiewicza w Poznaniu, Poznań 2014.

Kobosko J., KosmalowA.J., Nasze styszące dzieci, „Słyszę. Dwumiesięcznik dla osób z problemami słuchu i mowy”, październik 2002.

Kobosko J., Kosmalowa J., Styszące rodzeństwo dzieci głuchych i stabostyszacych - spojrzenie z różnych stron, „Słyszę. Dwumiesięcznik dla osób z problemami słuchu i mowy", wrzesień-październik 2010.

Kucharczyk A., Kiedy w rodzinie nie wszystkie dzieci stysza..., [w:] Młodzież głucha $i$ stabo styszaca w rodzinie i otaczającym świecie dla terapeutów, nauczycieli, wychowawców i rodziców, red. J. Kobosko, Stowarzyszenie Rodziców i Przyjaciół Dzieci i Młodzieży z Wadą Słuchu „Usłyszeć Świat”, Warszawa 2009.

Pisula E., Rodzice i rodzeństwo dzieci z zaburzeniami rozwoju, Wydawnictwo Uniwersytetu Warszawskiego, Warszawa 2007.

Przybył I., Siostry i bracia dzisiaj. Gwarancja i niepewność w relacji - nowe hipotezy na podstawie badań ankietowych, [w:] Role rodzinne między przystosowaniem a kreacja, red. I. Przybył, A. Żurek, Wydawnictwo Naukowe Wydziału Nauk Społecznych Uniwersytetu im. Adama Mickiewicza, Poznań 2016.

Sęk H., Cieślak R., Wsparcie społeczne - sposoby definiowania, rodzaje i źródła wsparcia, wybrane koncepcje teoretyczne, [w:] Wsparcie społeczne, stres i zdrowie, red. H. Sęk, R. Cieślak, Wydawnictwo Naukowe PWN, Warszawa 2004.

Stelter Ż., Realizacja ról rodzinnych w rodzinie z dzieckiem niepetnosprawnym, [w:] Rodzina z dzieckiem niepetnosprawnym-możliwości i ograniczenia rozwoju, red. H. Liberska, Difin, Warszawa 2011.

Twardowski A., Sytuacja psychologiczna rodzeństwa dzieci z niepetnosprawnościami (część 1), „Szkoła Specjalna” 2011, 2.

Twardowski A., Sytuacja psychologiczna rodzeństwa dzieci z niepetnosprawnościami (część 2), „Szkoła Specjalna” 2011, 3.

Winiarski M., Pedagogika społeczna humanistycznie zorientowana, [w:] Pedagogika społeczna: dokonania - aktualności - perspektywy. Podręcznik akademicki dla pedagogów, red. S. Kawula, Wydawnictwo Adam Marszałek, Torun 2001.

Wzorek A., Rodzina z dzieckiem z zaburzeniem stuchu- spojrzenie systemowe, „Psychoterapia" 2009, 4(151). 